\title{
Strand Displacement Activity of PrimPol
}

\author{
Elizaveta O. Boldinova ${ }^{1}$, Ekaterina A. Belousova ${ }^{2}$, Diana I. Gagarinskaya ${ }^{1}$, \\ Ekaterina A. Maltseva ${ }^{2}$, Svetlana N. Khodyreva ${ }^{2}$, Olga I. Lavrik ${ }^{2} D$ and Alena V. Makarova ${ }^{1, *(D)}$ \\ 1 Institute of Molecular Genetics, National Research Center "Kurchatov Institute", Kurchatov sq. 2, \\ 123182 Moscow, Russia; lizaboldinova@yandex.ru (E.O.B.); deanaw@yandex.ru (D.I.G.) \\ 2 Institute of Chemical Biology and Fundamental Medicine, Siberian Branch of the Russian Academy of \\ Sciences, 8 Lavrentiev Avenue, 630090 Novosibirsk, Russia; sheffield@ngs.ru (E.A.B.); \\ 060179@mail.ru (E.A.M.); svetakh@niboch.nsc.ru (S.N.K.); lavrik@niboch.nsc.ru (O.I.L.) \\ * Correspondence: amakarova-img@yandex.ru
}

Received: 26 October 2020; Accepted: 23 November 2020; Published: 27 November 2020

\begin{abstract}
Human PrimPol is a unique enzyme possessing DNA/RNA primase and DNA polymerase activities. In this work, we demonstrated that PrimPol efficiently fills a 5-nt gap and possesses the conditional strand displacement activity stimulated by $\mathrm{Mn}^{2+}$ ions and accessory replicative proteins RPA and PolDIP2. The DNA displacement activity of PrimPol was found to be more efficient than the RNA displacement activity and FEN1 processed the 5'-DNA flaps generated by PrimPol in vitro.
\end{abstract}

Keywords: PrimPol; strand displacement; RPA; PolDIP2; FEN1

\section{Introduction}

Human PrimPol is an archaeo-eukaryotic primase with DNA polymerase activity found in nuclei and mitochondria [1,2]. Unlike the complex of Pol $\alpha$-primase possessing RNA primase and DNA polymerase activities, PrimPol demonstrates DNA primase activity [1,2]. PrimPol also possesses an ability to anneal single stranded DNA (ssDNA) molecules based on microhomology and connect separate strands [3]. It has been suggested that the main function of PrimPol is re-initiation of stalled replication forks using de novo DNA synthesis and re-priming downstream DNA lesions and non-B DNA structures such as G-quadruplexes [4-7]. PrimPol also possesses DNA translesion activity. PrimPol efficiently and relatively accurately bypasses 8-oxoguanine and other non-bulky DNA lesions $[2,8]$.

During DNA repair and replication, DNA polymerases often carry out strand displacement DNA synthesis. Several human DNA polymerases possess the strand displacement activity: Pol $\delta[9,10]$, Pol $\beta$ [11-13], Pol $\eta[10,14-17]$, Pol $\kappa$ [15], as well as yeast Pol $\zeta[10,15,16]$, whereas Pol $\varepsilon$, Pol $\alpha$, and Pol $\gamma$ have limited ability for strand displacement and displace only $1-2$ nucleotides $[14,18,19]$. Many polymerases require accessory proteins, such as DNA helicases, to carry out strand displacement synthesis [20]. In cells, DNA polymerases might polymerize across a gap. Moreover, the presence of a $5^{\prime}$-phosphorylated downstream strand is critical for the highest catalytic efficiency of some DNA polymerases, such as Pol $\beta$ and Pol $\lambda$ [21].

The activity of PrimPol on DNA substrates with a gap and the ability of PrimPol to displace DNA strands has not been studied yet. In this article, we investigated how PrimPol responds to a gapped DNA structure and analyzed its ability to displace downstream DNA or RNA strands. We demonstrated that PrimPol possesses the DNA strand displacement activity, which is stimulated by $\mathrm{Mn}^{2+}$ ions, replication protein A (RPA) and polymerase delta-interacting protein 2 (PolDIP2), and that the resulting flap can be subsequently removed by FEN1. 


\section{Results}

\section{1. $\mathrm{Mn}^{2+}$ Ions Stimulate the DNA Strand Displacement Activity of PrimPol}

PrimPol utilizes both $\mathrm{Mg}^{2+}$ and $\mathrm{Mn}^{2+}$ ions. $\mathrm{Mn}^{2+}$ ions significantly stimulate the DNA polymerase and DNA primase activities of PrimPol but decrease the accuracy of dNMP incorporation [2,22,23].

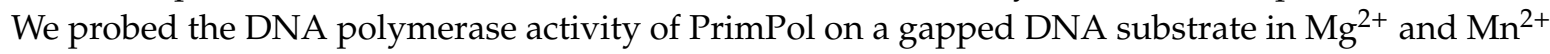
reactions (Figure 1). The 34-mer DNA substrate contained the 18-mer primer, the 5-nt gap with G or 8-oxoguanine (8-oxo-G) lesion in the +1 position, and the 11-mer locking DNA strand with the 5 '-phosphate. Simple primer extension reactions on DNA substrates without locking DNA strands were used as controls in parallel, to monitor the "pausing" and efficiency of the strand displacement activities analyzed (Figure 1A, lanes 1-4 and 9-12). PrimPol efficiently filled the gap containing undamaged G or 8-oxo-G (Figure 1A). Only trace DNA strand displacement activity of PrimPol was observed in the presence of $\mathrm{Mg}^{2+}$ ions (Figure 1A, lanes 5-8). In contrast, PrimPol was capable of displacing the 11-mer DNA oligonucleotide to make a 34 bp duplex DNA in the presence of $\mathrm{Mn}^{2+}$ ions (Figure 1B, lanes 13-16).

A
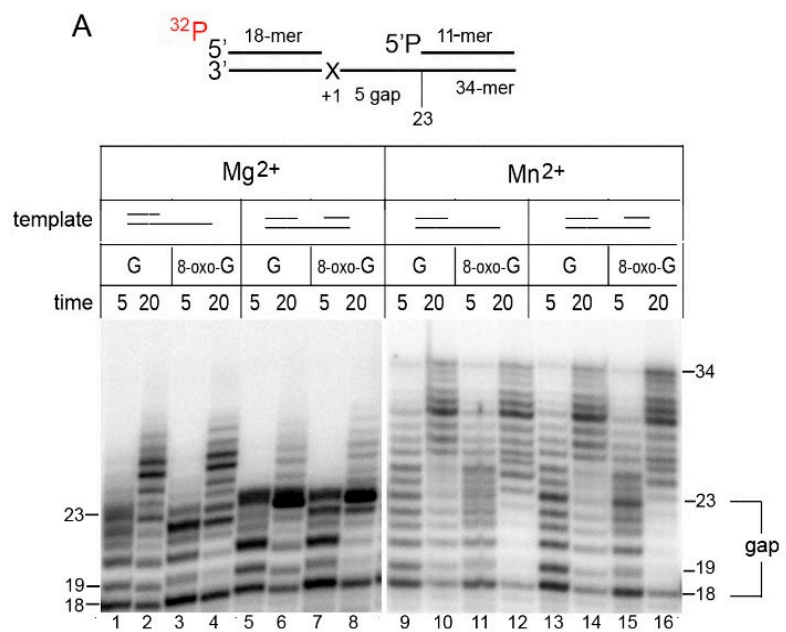
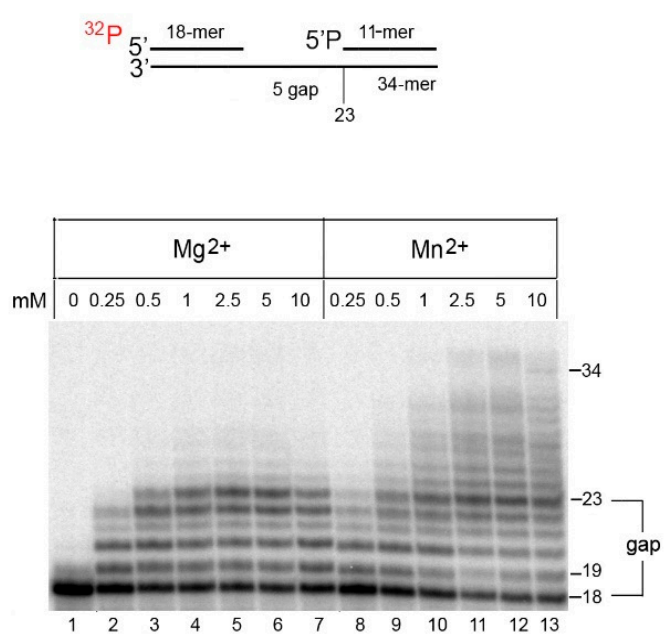

Figure 1. The strand displacement activity of PrimPol on DNA substrates with the 5-nt gap. (A) Strand displacement synthesis of PrimPol on a 34-mer DNA substrate. Primer extension reactions were carried out on DNA substrates with the 5-nt gap or with the $3^{\prime}$-recessed end in the presence of $1 \mathrm{mM}$ $\mathrm{Mg}^{2+}$ or $3 \mathrm{mM} \mathrm{Mn}^{2+}$ and $400 \mathrm{nM}$ PrimPol for $10 \mathrm{~min}$. The DNA template contains undamaged G or 8-oxoguanine (8-oxo-G) in the +1 position downstream of the primer. Denaturing urea-PAGE of gap-filling products is shown. (B) The effect of different $\mathrm{Mg}^{2+}$ and $\mathrm{Mn}^{2+}$ ion concentrations on the strand displacement synthesis by PrimPol. Primer extension reactions were carried out on a 34-mer undamaged DNA substrate with the 5-nt gap in the presence of $0.25-10 \mathrm{mM} \mathrm{Mg}^{2+}$ or $\mathrm{Mn}^{2+}$ and $100 \mathrm{nM}$ PrimPol for $10 \mathrm{~min}$. Denaturing urea-PAGE of gap-filling products is shown.

We also analyzed the ability of PrimPol to displace DNA in the presence of different $\mathrm{Mg}^{2+}$ and $\mathrm{Mn}^{2+}$. Processive DNA synthesis and the robust displacement of the 11-mer DNA strand by PrimPol were supported by 2.5-10 $\mathrm{mM} \mathrm{MnCl}_{2}$ (Figure 1B, lanes 11-13). A small amount of the 23-nt gap-filled product was accumulated, indicating a pause site and/or suggesting that the efficiency of DNA strand displacement synthesis is lower than gap-filling.

Next, we analyzed the DNA strand displacement activity of PrimPol in reactions with low $\mathrm{Mn}^{2+}$ concentrations and long locking DNA/RNA strands. We tested the DNA strand displacement activity of PrimPol on the 55-mer DNA substrate with the 32-mer locking DNA in the presence of $1 \mathrm{mM} \mathrm{Mn}^{2+}$ (Figure 2). In these conditions, the DNA strand displacement activity was relatively weak and only displacement of a few nucleotides was observed. The efficiency of DNA strand displacement by 
PrimPol was inferior to that of Pol $\eta$ (Figure 2, lanes 17-20) and comparable to Pol $\beta$ (Figure 2, lanes 13-16).

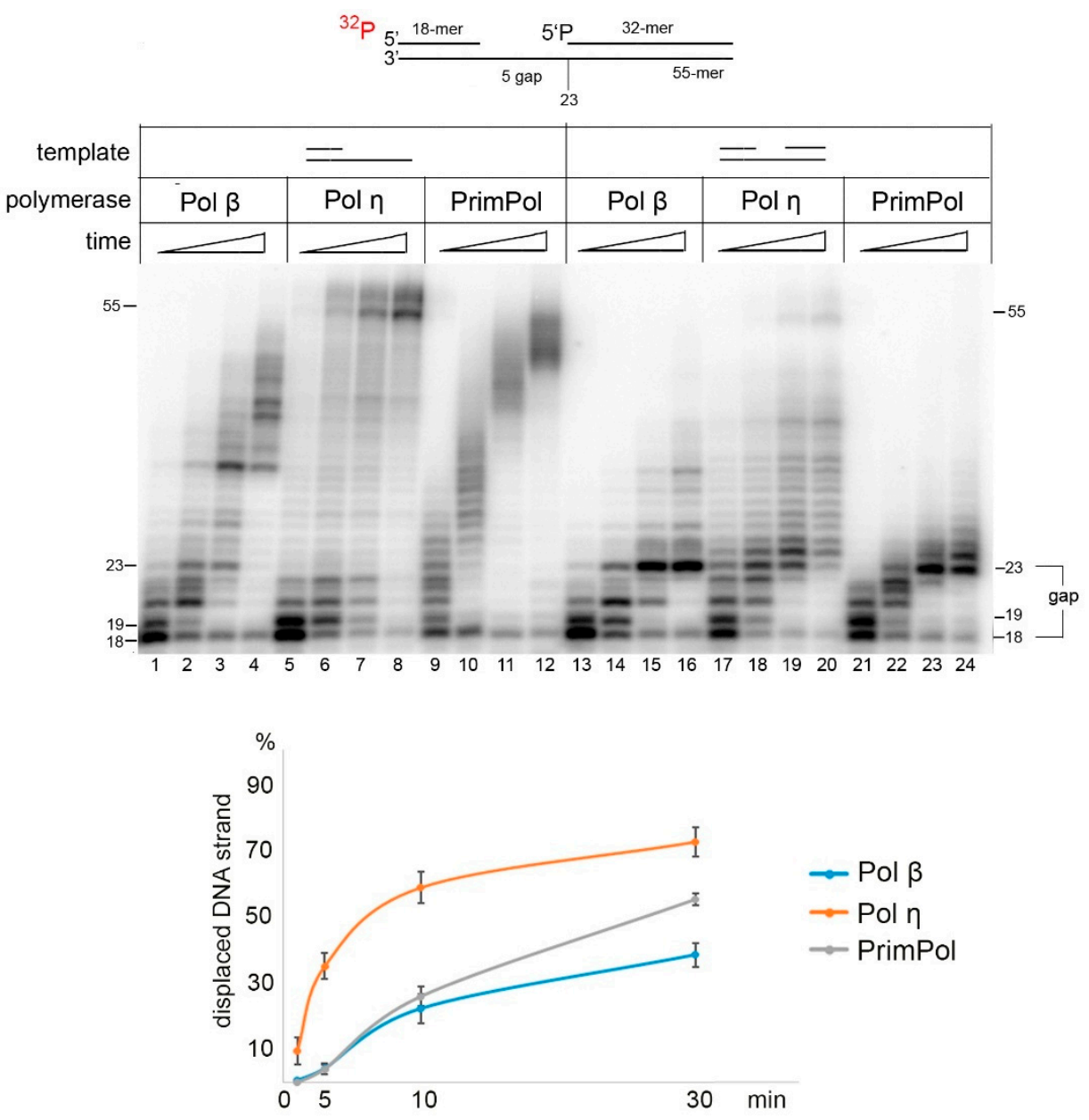

Figure 2. Comparison of DNA strand displacement synthesis between human Pol $\beta$, Pol $\eta$, and PrimPol. Primer extension reactions were carried out on a 55-mer DNA substrate with the 5-nt gap in the presence of $10 \mathrm{mM} \mathrm{Mg}^{2+}$ and $10 \mathrm{nM}$ Pol $\beta$ or Pol $\eta$, or in the presence of $1 \mathrm{mM} \mathrm{Mn}^{2+}$ and $100 \mathrm{nM}$ PrimPol for 1-30 min.

\subsection{RNA Strand Displacement Activity of PrimPol Is Not Efficient}

We also tested whether PrimPol is able to displace downstream RNA and analyzed the effect of the $5^{\prime}$-phosphate of the locking DNA/RNA strand (Figure 3). The RNA displacement activity of PrimPol was significantly less efficient than the DNA displacement activity (Figure 3, lanes 1-8 and 17-24). The 5'-phosphate had no effect on the DNA and RNA displacement synthesis by PrimPol (Figure 3, lanes 9-16 and lanes 25-32). 


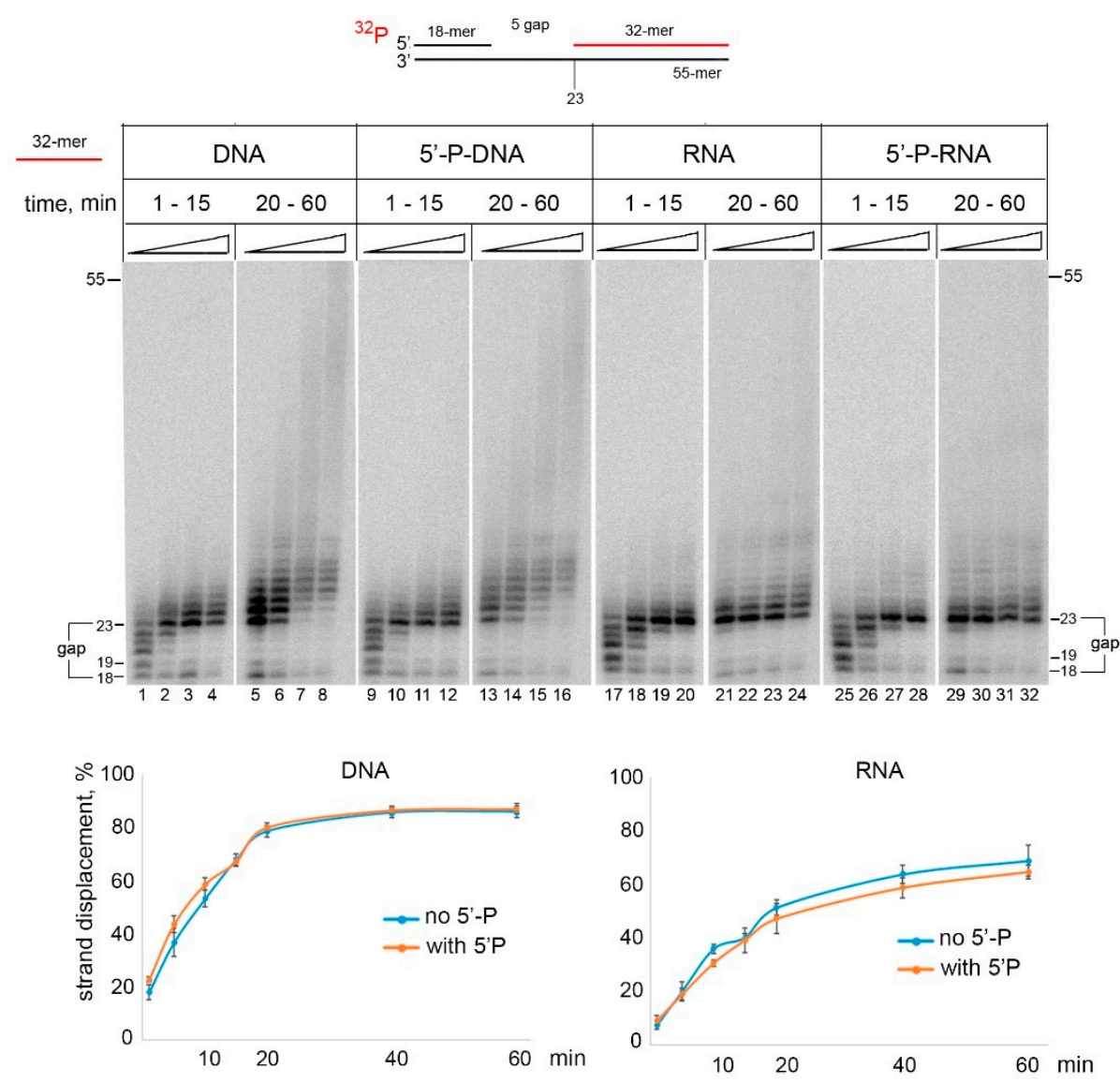

Figure 3. Characterization of PrimPol strand displacement activity. Primer extension reactions were carried out on DNA substrates with the gap containing 5'-phosphorylated or non-phosphorylated downstream DNA or RNA in the presence of $1 \mathrm{mM} \mathrm{Mn}^{2+}$ and $100 \mathrm{nM}$ PrimPol for 1-60 min. The percent of displaced primer (from +5 pause) was calculated for each reaction, and the mean values of displaced primers with the standard errors are shown on the diagrams.

\subsection{FEN1 Processes the 5'-Flaps Generated by PrimPol In Vitro}

Endonuclease FEN1 excises 5 '-flap structures in DNA during the long-patch BER $[13,24,25]$ and Okazaki fragment maturation [26]. We labeled the locking DNA strand at the $5^{\prime}$-end with 32P and monitored its electrophoretic mobility (Figure 4, bottom panel). FEN1 cleaved the $2-4$ nt $5^{\prime}$-flaps created by Pol $\beta$ (Figure 4, lanes 10-12) and PrimPol (Figure 4, lanes 13-15), and the $5^{\prime}-3^{\prime}$-exonuclease products of FEN1 (1 nt and $2 \mathrm{nt}$ ) were also observed in all reactions with FEN1 (Figure 4, lanes 7-15) [27]. In the presence of $\mathrm{Mn}^{2+}$ ions, PrimPol carried out more efficient DNA synthesis and/or strand displacement activity when FEN1 was added to the reaction. FEN1 eliminated the pausing observed during displacement of the locking DNA strand at the $23 \mathrm{nt}$ position of the DNA substrate. 

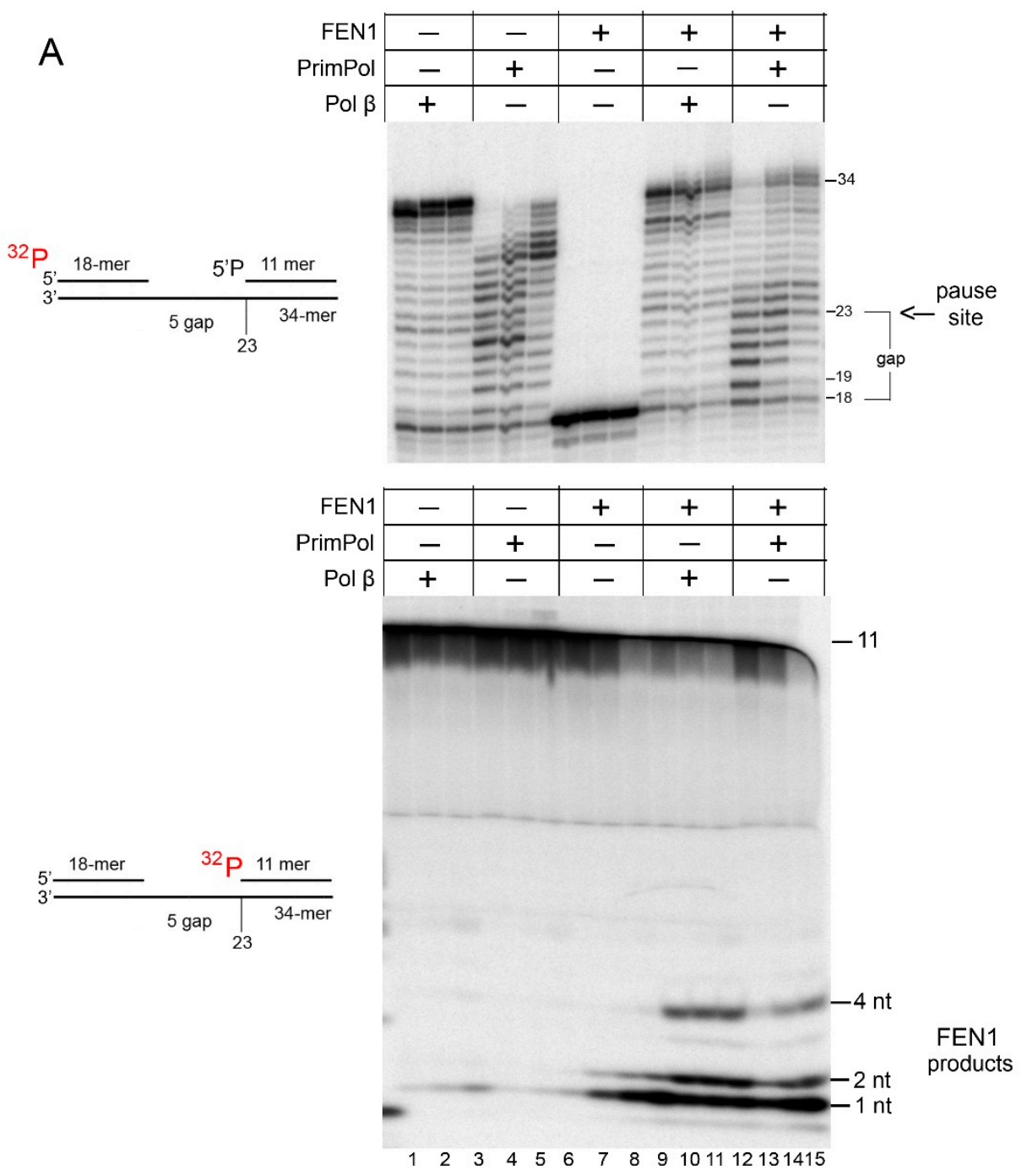

$\mathrm{B}$

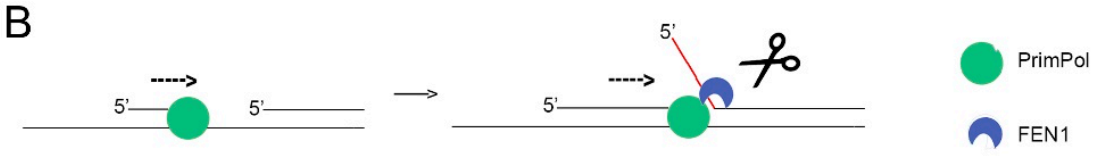

Figure 4. (A) Processing of PrimPol-generated $5^{\prime}$-flaps by FEN1. Primer extension reactions were carried out on the 32-mer DNA substrate with the gap containing $5^{\prime}-{ }^{32} \mathrm{P}$-labeled 18 -mer DNA primer or

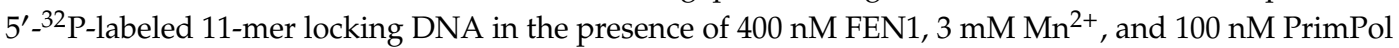
for 5-30 min. Probable lengths of FEN1 products are shown on the gel. (B) The scheme of the $5^{\prime}$-flap cleavage by FEN1.

\subsection{The Strand Displacement Activity of PrimPol Is Stimulated by PolDIP2 and RPA}

We also analyzed the DNA strand displacement activity of PrimPol in the presence of PolDIP2 and RPA accessory proteins. Previously, it was shown that PolDIP2 and RPA functionally interact with PrimPol and stimulate its DNA polymerase activity [28-30]. In agreement with these studies, PolDIP2 significantly stimulated the DNA strand displacement activity of PrimPol on the DNA substrate with a gap in the presence of $\mathrm{Mn}^{2+}$ ions (Figure 5, lanes 17-20). Importantly, PrimPol demonstrated the DNA strand displacement activity in the presence of PolDIP2 (but not RPA), even in $\mathrm{Mg}^{2+}$-reaction conditions (Figure 5, lanes 5-8). The stimulation of strand displacement synthesis by RPA (under equimolar RPA to DNA ratios) was observed only in the presence of $\mathrm{Mn}^{2+}$ ions (Figure 5, lanes 21-24). 


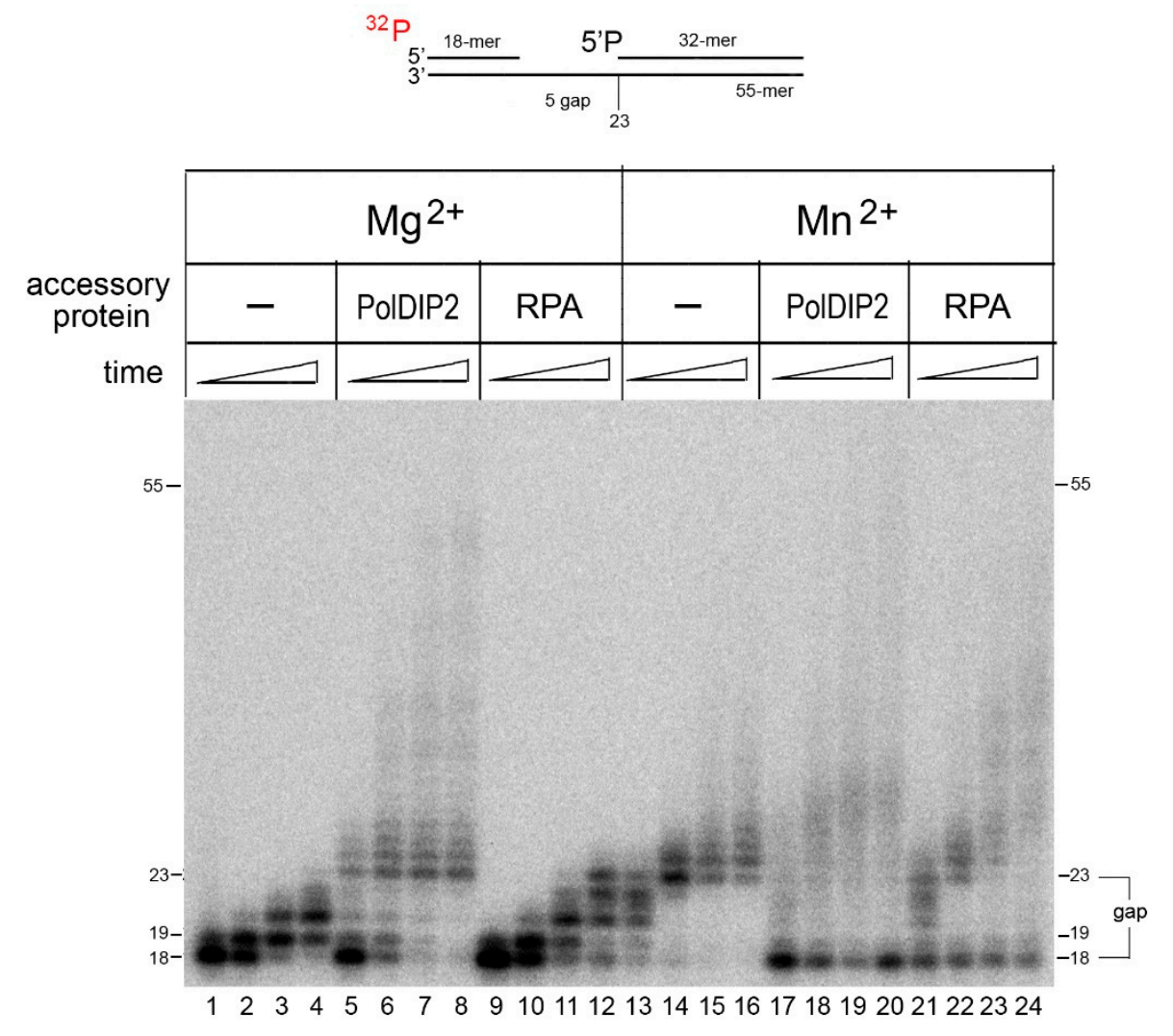

Figure 5. The effect of PolDIP2 and RPA on the DNA strand displacement activity of PrimPol. Primer extension reactions were carried out on DNA substrates with the gap containing $5^{\prime}$-phosphorylated downstream DNA in the presence of $10 \mathrm{mM} \mathrm{Mg}^{2+}$ or $1 \mathrm{mM} \mathrm{Mn}^{2+}$ and $100 \mathrm{nM}$ PrimPol for 1-20 min.

\section{Discussion}

In this work, we demonstrated that human PrimPol efficiently fills the 5-nt gap and possesses the conventional DNA strand displacement activity in the presence of $\mathrm{Mn}^{2+}$ but not $\mathrm{Mg}^{2+}$ ions. The presence of the $5^{\prime}$-phosphate on the downstream DNA strand did not increase the activity of PrimPol on gapped DNA. These data are consistent with the role of $\mathrm{Mn}^{2+}$ ions in the stimulation of the DNA polymerase and primase activities of PrimPol, as well as the stimulation of DNA damage bypass [2,8,22,23]. Efficient gap-filling synthesis was also observed on gapped DNA with 8-oxo-G lesion. Efficient 8-oxo-G bypass on DNA substrates with $5^{\prime}$-recessed ends was demonstrated previously $[2,8,23]$.

In cells, strand displacement activity of PrimPol can be stimulated by replication accessory factors, such as proteins recruiting PrimPol to DNA and enzymes involved in a $5^{\prime}$-flap cleavage. PrimPol does not interact with proliferating cell nuclear antigen (PCNA), but another protein functionally interacting with several DNA polymerases [31] — PolDIP2 — stimulates the DNA polymerase activity of PrimPol [28]. The interaction between PrimPol and PolDIP2 was demonstrated by cross-linking and mass spectrometry analysis [28]. RPA recruits PrimPol to the sites of DNA damage and stimulates its DNA polymerase and DNA primase activities [29,30,32]. RPA takes part in the assembly and coordination of the replication fork due to its protein-protein interactions [33]. In this work, we demonstrated that the DNA strand displacement activity of PrimPol can be stimulated by both replicative accessory proteins on a DNA substrate with the 5-nt gap. RPA efficiently binds long ssDNA molecules and shows a stable $30 \mathrm{nt}$ binding mode [34]. However, RPA also binds 4-6 nucleotides [35] and utilizes a ssDNA binding site with the size of 8-10 nucleotides [35,36]. The mode of RPA binding is dependent on the length of the ssDNA platform, as well as on the ratio of RPA:DNA concentration [37]. RPA also contacts flaps in DNA with a short gap [36]. Possibly, the stimulation of the strand displacement activity of PrimPol by RPA can be explained by the physical interaction of 
polymerase with RPA and its additional attraction to the ssDNA part of the gap from the $5^{\prime}$-side by RPA associated with the flap.

Endonuclease FEN1 excises 5'-flap structures in DNA during the long-patch BER $[13,24,25]$ and stimulates the DNA strand displacement activity of Pol $\beta$ and Pol $\lambda$ [11-13]. FEN1 also physically interacts with Pol $\beta$ [12] and plays a role in the long-patch BER in nuclei $[13,25]$ and mitochondria [38]. The complex of Pol $\delta$-PCNA-FEN1 removes RNA primers during Okazaki fragment maturation [26]. Importantly, FEN1 was found among the proteins interacting with PrimPol using mass spectrometry [39]. We showed that PrimPol cooperates with FEN1 to displace and remove downstream DNA strand in vivo (Figure 4B). Possibly, FEN1 can cooperate with PrimPol to perform stepwise strand displacement synthesis in the nucleus and/or mitochondria.

Altogether, our data suggest that PrimPol can realize the DNA strand displacement activity in vivo. However, the functional importance of the strand displacement activity of PrimPol is not clear. The process of strand displacement synthesis is involved in many DNA transactions in vivo, such as d-loop invasion in homologous recombination and break-induced replication, non-homologous end-joining and microhomology-mediated end-joining, long-patch base excision repair, and Okazaki fragment maturation. However, human PrimPol has not been reported to be involved in these processes. The unusual ability of PrimPol to connect separate DNA strands [3], together with the DNA strand displacement activity, opens up the possibility of a role of PrimPol in microhomology-mediated end-joining. Additionally, it is possible that PrimPol in cooperation with nucleases and/or helicases (such as FEN1, Twinkle, or DNA2) might realize the strand displacement activity during re-priming events of mitochondrial DNA replication. Interestingly, the RNA displacement activity of PrimPol was not efficient, suggesting that PrimPol is blocked after encountering an Okazaki fragment.

\section{Materials and Methods}

\subsection{Proteins}

PrimPol was purified as described [40]. The full-length PolDIP2 coding gene was cloned into the pGEX6P1 plasmid in frame with an N-terminal GST-tag. PolDIP2 was expressed at $22^{\circ} \mathrm{C}$ after induction with $0.5 \mathrm{mM}$ isopropyl $\beta$ - d-1-thiogalactopyranoside in $6 \mathrm{~L}$ of Rosetta 2 Escherichia coli cells and purified as described for PrimPol in three steps: (1) batch binding to $1 \mathrm{~mL}$ of glutathione-sepharose resin (GE Healthcare, Chicago, IL, USA), (2) the GST-tag cleavage with 3C protease, and (3) $1 \mathrm{~mL}$ HiTrap Heparin HP column (GE Healthcare, Chicago, IL, USA) chromatography. PolDIP2 was eluted at $250 \mathrm{mM}$ $\mathrm{KCl}$, aliquoted and stored at $-80^{\circ} \mathrm{C}$. PolDIP2 aliquots were discarded after each experiment to avoid freeze-thaw-refreeze cycles. FEN1 and RPA were purified as described [41,42]. Fractions containing substoichiometric RPA were discarded, and RPA with 1:1:1 stoichiometry of RPA1:RPA2:RPA3 subunits was used in experiments. Preparations of PolDIP2, FEN1, and RPA (Supplementary Materials Figure S1) were free of contaminating DNA polymerase activity.

\subsection{DNA Substrates}

Oligonucleotide substrates and primers were synthetized at the "DNA Synthes" company (Moscow, Russia). To obtain DNA substrates for the primer extension reactions, the primers were $5^{\prime}$-labeled with $\gamma-\left[{ }^{32} \mathrm{P}\right]$-ATP by T4 polynucleotide kinase (SibEnzyme, Novosibirsk, Russia) and annealed to the corresponding unlabeled template oligonucleotides at a molar ratio of 1:1.1, heated to $95^{\circ} \mathrm{C}$, and slowly cooled down to $20^{\circ} \mathrm{C}$. To purify the labeled locking DNA strand (used in the experiment with FEN1), unreacted $\gamma-\left[{ }^{32} \mathrm{P}\right]-\mathrm{ATP}$ was removed on a MicroSpinTM G-25 column (Amersham Pharmacia Biotech, GE Healthcare, Chicago, IL, USA), and the labeled oligonucleotide was precipitated from the solution by $4 \% \mathrm{LiClO}_{4}$ in acetone.

DNA substrates for strand displacement reactions were obtained by annealing $5^{\prime}\left[{ }^{32} \mathrm{P}\right]$-labeled primer, unlabeled template, and unlabeled downstream oligonucleotide at a molar ratio of 1:1:1. The sequences of the oligonucleotides used in this study are shown in Table 1. 
Table 1. Oligonucleotides used in the study.

\begin{tabular}{|c|c|}
\hline Primer & 5'-CGGTATCCACCAGGTCTG-3' \\
\hline 34-mer DNA template & $\begin{array}{c}\text { 5'-GGCTTCATCGTTGTCXCAGACCTGGTGGATACCG-3' }^{\prime} \\
\text { X = G or 8-oxo-G }\end{array}$ \\
\hline 55-mer DNA template & 5'-GACTACATTTCATCTGGCTTGGGCTTCATCGTTGTCGCAGACCTGGTGGATACCG-3' \\
\hline $\begin{array}{l}\text { Locking primer } 1 \text { (11-mer } \\
\text { 5'-P-DNA) }\end{array}$ & $5^{\prime}-(\mathrm{P})$ ACGATGAAGCC-3'(P)-phosphate \\
\hline $\begin{array}{c}\text { Locking primer } 2 \text { (11-mer } \\
\text { DNA) }\end{array}$ & $5^{\prime}$-ACGATGAAGCC-3' \\
\hline $\begin{array}{l}\text { Locking primer } 3 \text { (32-mer } \\
5^{\prime} \text {-P-DNA) }\end{array}$ & $\begin{array}{l}\text { 5'-(P)ACGATGAAGCCCAAGCCAGATGAAATGTAGTC-3' }^{\text {(P) - phosphate }}\end{array}$ \\
\hline $\begin{array}{c}\text { Locking primer } 4 \text { (32-mer } \\
\text { DNA) }\end{array}$ & 5'-ACGATGAAGCCCAAGCCAGATGAAATGTAGTC-3' \\
\hline $\begin{array}{l}\text { Locking primer } 5 \text { (32-mer } \\
5^{\prime} \text {-P-RNA) }\end{array}$ & $\begin{array}{l}\text { 5'-(P)ACGAUGAAGCCCAAGCCAGAUGAAAUGUAGUC-3' }^{(\mathrm{P}) \text { - phosphate }}\end{array}$ \\
\hline $\begin{array}{l}\text { Locking primer } 6 \text { (32-mer } \\
\text { RNA) }\end{array}$ & 5'- ACGAUGAAGCCCAAGCCAGAUGAAAUGUAGUC-3' \\
\hline
\end{tabular}

\subsection{Primer Extension Reactions}

Primer extension reactions with PrimPol were carried out in $20 \mu \mathrm{L}$ of reaction buffer containing $30 \mathrm{mM}$ HEPES (pH 7.0), $8 \%$ glycerol, $0.1 \mathrm{mg} / \mathrm{mL}$ bovine serum albumin, $0.25-10 \mathrm{mM} \mathrm{MgCl}{ }_{2}$ or $\mathrm{MnCl}_{2}$, $20 \mathrm{nM}$ DNA substrate, $200 \mu \mathrm{M}$ dNTPs, and 100 or $400 \mathrm{nM}$ PrimPol. Some reactions were supplemented with $300 \mathrm{nM}$ PolDIP2 or $20 \mathrm{nM}$ RPA. Standard reactions with Pol $\beta$ and Pol $\eta$ were carried out in $20 \mu \mathrm{L}$ of reaction buffer containing $30 \mathrm{mM}$ HEPES ( $\mathrm{pH} 7.4$ ), $8 \%$ glycerol, $0.1 \mathrm{mg} / \mathrm{mL}$ bovine serum albumin, $10 \mathrm{mM} \mathrm{MgCl} 2,20 \mathrm{nM}$ DNA substrate, $50 \mu \mathrm{M}$ dNTPs, and $10 \mathrm{nM}$ of polymerase. Reactions with FEN1 were carried out with $30 \mathrm{nM}$ Pol $\beta$ or $400 \mathrm{nM}$ PrimPol and $400 \mathrm{nM}$ FEN1. Locking oligonucleotides with $5^{\prime}$-phosphates was used in the experiments unless specified in figure legends.

Reactions were started by adding dNTPs and were incubated at $37^{\circ} \mathrm{C}$ at different times as indicated in the figure legends. The reactions were terminated by the addition of $20 \mu \mathrm{L}$ of loading buffer containing 95\% formamide, $10 \mathrm{mM}$ EDTA, and $0.1 \%$ bromophenol blue. DNA products were resolved on $21 \%$ or $30 \%$ denaturing PAGE and detected by phosphor imaging on Typhoon 9400 (GE Healthcare, Chicago, IL, USA). Experiments were repeated 3-4 times. To estimate the efficiency of strand displacement, the percentage of displaced DNA was calculated: The total intensity of bands of displaced DNA starting from +6 position (the band above the mark 23 ) was divided by the total intensity of all bands of displaced DNA and the +5 position band (marked as 23 ) corresponding to the pause site.

Supplementary Materials: The following are available online at http://www.mdpi.com/1422-0067/21/23/9027/s1.

Author Contributions: Conceptualization, A.V.M. and O.I.L.; funding acquisition, A.V.M.; investigation, E.O.B., A.V.M., D.I.G., E.A.B., E.A.M., and S.N.K.; supervision, A.V.M. and O.I.L.; writing-original draft, A.V.M.; writing-review and editing, E.A.B. and O.I.L. All authors have read and agreed to the published version of the manuscript.

Funding: This work was funded by grants from the Russian Scientific Foundation (grant 18-14-00354).

Acknowledgments: We thank S. Wanrooij (Umea University, Sweden) for providing gene encoding PolDIP2.

Conflicts of Interest: The authors declare no conflict of interest. The funders had no role in the design of the study; in the collection, analyses, or interpretation of data; in the writing of the manuscript; or in the decision to publish the results.

\section{Abbreviations}

ssDNA Single-stranded DNA

8-oxo-G 8-oxoguanine 


\section{References}

1. Bianchi, J.J.; Rudd, S.G.; Jozwiakowski, S.K.; Bailey, L.J.; Soura, V.; Taylor, E.; Stevanovic, I.; Green, A.J.; Stracker, T.H.; Lindsay, H.D.; et al. PrimPol bypasses UV photoproducts during eukaryotic chromosomal DNA replication. Mol. Cell 2013, 52, 566-573. [CrossRef]

2. García-Gómez, S.; Reyes, A.; Martínez-Jiménez, M.I.; Chocrón, S.; Mourón, S.; Terrados, G.; Powell, C.; Salido, E.; Méndez, J.; Holt, I.J.; et al. PrimPol, an archaic primase/polymerase operating in human cells. Mol. Cell 2013, 52, 541-553. [CrossRef]

3. Martínez-Jiménez, M.I.; García-Gómez, S.; Bebenek, K.; Sastre-Moreno, G.; Calvo, P.A.; Díaz-Talavera, A.; Kunkel, T.A.; Blanco, L. Alternative solutions and new scenarios for translesion DNA synthesis by human PrimPol. DNA Repair 2015, 29, 127-138. [CrossRef] [PubMed]

4. Kobayashi, K.; Guilliam, T.A.; Tsuda, M.; Yamamoto, J.; Bailey, L.J.; Iwai, S.; Takeda, S.; Doherty, A.J.; Hirota, K. Repriming by PrimPol is critical for DNA replication restart downstream of lesions and chain-terminating nucleosides. Cell Cycle 2016, 15, 1997-2008. [CrossRef] [PubMed]

5. Mourón, S.; Rodriguez-Acebes, S.; Martínez-Jiménez, M.I.; García-Gómez, S.; Chocrón, S.; Blanco, L.; Méndez, J. Repriming of DNA synthesis at stalled replication forks by human PrimPol. Struct. Mol. Biol. 2013, 20, 1383-1389. [CrossRef] [PubMed]

6. Schiavone, D.; Jozwiakowski, S.K.; Romanello, M.; Guilbaud, G.; Guilliam, T.A.; Bailey, L.J.; Sale, J.E.; Doherty, A.J. PrimPol Is Required for Replicative Tolerance of G Quadruplexes in Vertebrate Cells. Mol. Cell 2016, 61, 161-169. [CrossRef]

7. Torregrosa-Muñumer, R.; Forslund, J.M.E.; Goffart, S.; Pfeiffer, A.; Stojkovič, G.; Carvalho, G.; Al-Furoukh, N.; Blanco, L.; Wanrooij, S.; Pohjoismäki, J.L.O. PrimPol is required for replication reinitiation after mtDNA damage. Proc. Natl. Acad. Sci. USA 2017, 114, 11398-11403. [CrossRef]

8. Makarova, A.V.; Boldinova, E.O.; Belousova, E.A.; Lavrik, O.I. In Vitro lesion bypass by human PrimPol. DNA Repair 2018, 70, 18-24. [CrossRef]

9. Maga, G.; Villani, G.; Tillement, V.; Stucki, M.; Locatelli, G.A.; Frouin, I.; Spadari, S.; Hübscher, U. Okazaki fragment processing: Modulation of the strand displacement activity of DNA polymerase delta by the concerted action of replication protein A, proliferating cell nuclear antigen, and flap endonuclease-1. Proc. Natl. Acad. Sci. USA 2001, 98, 14298-14303. [CrossRef]

10. Sebesta, M.; Burkovics, P.; Juhasz, S.; Zhang, S.; Szabo, J.E.; Lee, M.Y.W.T.; Haracska, L.; Krejci, L. Role of PCNA and TLS polymerases in D-loop extension during homologous recombination in humans. DNA Repair 2013, 12, 691-698. [CrossRef]

11. Lebedeva, N.A.; Rechkunova, N.I.; Dezhurov, S.V.; Khodyreva, S.N.; Favre, A.; Blanco, L.; Lavrik, O.I. Comparison of functional properties of mammalian DNA polymerase $\lambda$ and DNA polymerase $\beta$ in reactions of DNA synthesis related to DNA repair. Biochim. Biophys. Acta 2005, 1751, 150-158. [CrossRef] [PubMed]

12. Maga, G.; van Loon, B.; Crespan, E.; Villani, G.; Hübscher, U. The Block of DNA Polymerase $\delta$ Strand Displacement Activity by an Abasic Site Can Be Rescued by the Concerted Action of DNA Polymerase $\beta$ and Flap Endonuclease 1. J. Biol. Chem. 2009, 284, 14267-14275. [CrossRef] [PubMed]

13. Prasad, R.; Dianov, G.L.; Bohr, V.A.; Wilson, S.H. FEN1 stimulation of DNA polymerase beta mediates an excision step in mammalian long patch base excision repair. J. Biol. Chem. 2000, 275, 4460-4466. [CrossRef]

14. Ganai, R.A.; Zhang, X.-P.; Heyer, W.-D.; Johansson, E. Strand displacement synthesis by yeast DNA polymerase $\varepsilon$. Nucleic Acids Res. 2016, 44, 8229-8240. [CrossRef] [PubMed]

15. Ho, T.V.; Guainazzi, A.; Derkunt, S.B.; Enoiu, M.; Schärer, O.D. Structure-dependent bypass of DNA interstrand crosslinks by translesion synthesis polymerases. Nucleic Acids Res. 2011, 39, 7455-7464. [CrossRef]

16. Li, J.; Holzschu, D.L.; Sugiyama, T. PCNA is efficiently loaded on the DNA recombination intermediate to modulate polymerase $\delta, \eta$, and $\zeta$ activities. Proc. Natl. Acad. Sci. USA 2013, 110, 7672-7677. [CrossRef]

17. McIlwraith, M.J.; Vaisman, A.; Liu, Y.; Fanning, E.; Woodgate, R.; West, S.C. Human DNA polymerase eta promotes DNA synthesis from strand invasion intermediates of homologous recombination. Mol. Cell 2005, 20, 783-792. [CrossRef]

18. He, Q.; Shumate, C.K.; White, M.A.; Molineux, I.J.; Yin, Y.W. Exonuclease of human DNA polymerase gamma disengages its strand displacement function. Mitochondrion 2013, 13, 592-601. [CrossRef] 
19. Podust, V.N.; Hübscher, U. Lagging strand DNA synthesis by calf thymus DNA polymerases alpha, beta, delta and epsilon in the presence of auxiliary proteins. Nucleic Acids Res. 1993, 21, 841-846. [CrossRef]

20. Giannattasio, M.; Branzei, D. DNA Replication Through Strand Displacement During Lagging Strand DNA Synthesis in Saccharomyces cerevisiae. Genes 2019, 10, 167. [CrossRef]

21. Brown, J.A.; Pack, L.R.; Sanman, L.E.; Suo, Z. Efficiency and fidelity of human DNA polymerases $\lambda$ and $\beta$ during gap-filling DNA synthesis. DNA Repair 2011, 10, 24-33. [CrossRef] [PubMed]

22. Mislak, A.C.; Anderson, K.S. Insights into the Molecular Mechanism of Polymerization and Nucleoside Reverse Transcriptase Inhibitor Incorporation by Human PrimPol. Agents Chemother. 2015, 60, 561-569. [CrossRef] [PubMed]

23. Zafar, M.K.; Ketkar, A.; Lodeiro, M.F.; Cameron, C.E.; Eoff, R.L. Kinetic analysis of human PrimPol DNA polymerase activity reveals a generally error-prone enzyme capable of accurately bypassing 7,8-dihydro-8-oxo-2'-deoxyguanosine. Biochemistry 2014, 53, 6584-6594. [CrossRef] [PubMed]

24. Harrington, J.J.; Lieber, M.R. The characterization of a mammalian DNA structure-specific endonuclease. EMBO J. 1994, 13, 1235-1246. [CrossRef] [PubMed]

25. Prasad, R.; Lavrik, O.; Kim, S.J.; Kedar, P.; Yang, X.P.; Vande Berg, B.J.; Wilson, S.H. DNA polymerase beta -mediated long patch base excision repair. Poly(ADP-ribose)polymerase-1 stimulates strand displacement DNA synthesis. J. Biol. Chem. 2001, 276, 32411-32414. [CrossRef]

26. Stodola, J.L.; Burgers, P.M. Resolving individual steps of Okazaki-fragment maturation at a millisecond timescale. Nat. Struct. Mol. Biol. 2016, 23, 402-408. [CrossRef]

27. Tom, S.; Henricksen, L.A.; Bambara, R.A. Mechanism whereby proliferating cell nuclear antigen stimulates flap endonuclease 1. J. Biol. Chem. 2000, 275, 10498-10505. [CrossRef]

28. Guilliam, T.A.; Bailey, L.J.; Brissett, N.C.; Doherty, A.J. PolDIP2 interacts with human PrimPol and enhances its DNA polymerase activities. Nucleic Acids Res. 2016, 44, 3317-3329. [CrossRef]

29. Martínez-Jiménez, M.I.; Lahera, A.; Blanco, L. Human PrimPol activity is enhanced by RPA. Sci. Rep. 2017, 7, 783. [CrossRef]

30. Guilliam, T.A.; Brissett, N.C.; Ehlinger, A.; Keen, B.A.; Kolesar, P.; Taylor, E.M.; Bailey, L.J.; Lindsay, H.D.; Chazin, W.J.; Doherty, A.J. Molecular basis for PrimPol recruitment to replication forks by RPA. Nat. Commun. 2017, 8, 15222. [CrossRef]

31. Gagarinskaya, D.I.; Makarova, A.V. A multifunctional protein PolDIP2 in DNA translesion synthesis. Adv. Exp. Med. Biol. 2020, 1241, 35-45. [PubMed]

32. Wan, L.; Lou, J.; Xia, Y.; Su, B.; Liu, T.; Cui, J.; Sun, Y.; Lou, H.; Huang, J. hPrimpol1/CCDC111 is a human DNA primase-polymerase required for the maintenance of genome integrity. EMBO Rep. 2013, 14, 1104-1112. [CrossRef] [PubMed]

33. Maréchal, A.; Zou, L. RPA-coated single-stranded DNA as a platform for post-translational modifications in the DNA damage response. Cell Res. 2015, 25, 9-23. [CrossRef] [PubMed]

34. Blackwell, L.J.; Borowiec, J.A. Human replication protein A binds single-stranded DNA in two distinct complexes. Mol. Cell Biol. 1994, 14, 3993-4001. [CrossRef] [PubMed]

35. Bochkarev, A.; Pfuetzner, R.A.; Edwards, A.M.; Frappier, L. Structure of the single-stranded-DNA-binding domain of replication protein A bound to DNA. Nature 1997, 385, 176-181. [CrossRef] [PubMed]

36. Krasikova, Y.S.; Rechkunova, N.I.; Maltseva, E.A.; Lavrik, O.I. RPA and XPA interaction with DNA structures mimicking intermediates of the late stages in nucleotide excision repair. PLoS ONE 2018, 13, e0190782. [CrossRef] [PubMed]

37. Lavrik, O.I.; Kolpashchikov, D.M.; Weisshart, K.; Nasheuer, H.P.; Khodyreva, S.N.; Favre, A. RPA subunit arrangement near the $3^{\prime}$-end of the primer is modulated by the length of the template strand and cooperative protein interactions. Nucleic Acids Res. 1999, 27, 4235-4240. [CrossRef]

38. Liu, P.; Qian, L.; Sung, J.S.; de Souza-Pinto, N.C.; Zheng, L.; Bogenhagen, D.F.; Bohr, V.A.; Wilson, D.M., 3rd; Shen, B.; Demple, B. Removal of Oxidative DNA Damage via FEN1-Dependent Long-Patch Base Excision Repair in Human Cell Mitochondria. Mol. Cell Biol. 2008, 28, 4975-4987. [CrossRef]

39. Rudd, S.G. Cellular and Biochemical Characterisation of PrimPol, a Novel Eukaryotic Primase-Polymerase Involved in DNA Damage Tolerance. Ph.D. Thesis, University of Sussex, Brighton, UK, 2013.

40. Boldinova, E.O.; Stojkovič, G.; Khairullin, R.; Wanrooij, S.; Makarova, A.V. Optimization of the expression, purification and polymerase activity reaction conditions of recombinant human PrimPol. PLoS ONE 2017, 12, e0184489. [CrossRef] 
41. Binz, S.K.; Dickson, A.M.; Haring, S.J.; Wold, M.S. Functional assays for replication protein A (RPA). Methods Enzymol. 2006, 409, 11-38.

42. Nazarkina, J.K.; Petrousseva, I.O.; Safronov, I.V.; Lavrik, O.I.; Khodyreva, S.N. Interaction of Flap Endonuclease-1 and Replication Protein A with Photoreactive Intermediates of DNA Repair. Biochemistry (Mosc) 2003, 68, 934-942. [CrossRef] [PubMed]

Publisher's Note: MDPI stays neutral with regard to jurisdictional claims in published maps and institutional affiliations.

(C) 2020 by the authors. Licensee MDPI, Basel, Switzerland. This article is an open access article distributed under the terms and conditions of the Creative Commons Attribution (CC BY) license (http://creativecommons.org/licenses/by/4.0/). 